\title{
Idiopathic calcinosis cutis of the scrotum: a case report and review of the literature
}

\author{
M. M. Aarif Syed ${ }^{1 *}$ (D, Aasiya Rajbhandari ${ }^{2}$ and Upama Paudel ${ }^{1}$
}

\begin{abstract}
Background: Abnormal deposition of calcium in the skin or subcutaneous tissue is termed calcinosis cutis. Idiopathic calcinosis cutis of the scrotum is an uncommon entity. The pathogenesis of idiopathic calcinosis cutis of the scrotum is debatable. The condition presents as several brown to yellowish nodules on the scrotum, gradually progressive, and mostly asymptomatic. Here we report a case of idiopathic calcinosis cutis of the scrotum with a brief review of the literature and a discussion on pathogenesis.

Case presentation: A healthy looking, 50-year-old Nepali man presented with multiple growths on his scrotum for 15 years, which were mostly asymptomatic with an occasional complaint of itching. On physical examination, multiple pink to brown nodules ranging in size from $0.5 \times 0.5 \times 0.5 \mathrm{~cm}$ to $3 \times 3 \times 1 \mathrm{~cm}$, which were painless and firm in consistency, were noted. On laboratory examinations the following were found to be within normal limits: serum calcium, phosphorus, parathyroid hormone, and vitamin D hormone levels; uric acid; alkaline phosphatase; and lipid profile. Based on clinical features and laboratory reports, a diagnosis of idiopathic calcinosis cutis of the scrotum was made. The nodules were excised under local anesthesia in several sittings, which gave a good cosmetic result with no evidence of recurrence in 1-year follow-up period. A histopathological examination revealed dermis with areas of fibrosis and calcification along with numerous multinucleated giant cells and an absence of any cystic structure.

Conclusions: Idiopathic calcinosis cutis of the scrotum is a benign condition, which remains mostly asymptomatic. It presents as progressive multiple nodules of varying numbers and sizes. A histopathological evaluation reveals areas of calcification. The cause is either dystrophic calcification of cysts or idiopathic. Excision is the treatment of choice.
\end{abstract}

Keywords: Calcinosis cutis, Scrotum, Idiopathic, Dystrophic

\section{Background}

Abnormal deposition of calcium in the skin or subcutaneous tissue is termed calcinosis cutis. Skin is not a site for collection of calcium and is always a pathological phenomenon. Calcinosis cutis can involve any part of the skin. Depending on the cause, calcinosis cutis is classified into four types: dystrophic, metastatic, idiopathic, and iatrogenic [1]. Idiopathic calcinosis can present in genital skin that includes vulva, penis, or scrotum. Idiopathic calcinosis cutis of the scrotum (ICCS), also called idiopathic scrotal calcinosis, is an uncommon entity and was first described by Lewinski in 1883 [2]. In recent times, there has been a debate on the pathogenesis of

\footnotetext{
* Correspondence: syedmmaarif@gmail.com

${ }^{1}$ Department of Dermatology and Venereology, Institute of Medicine,

Tribhuvan University, Maharajgunj, Kathmandu, Nepal

Full list of author information is available at the end of the article
}

scrotal calcinosis, with questions being raised on its idiopathic nature $[3,4]$. The lesions are mostly asymptomatic and have great variation in sizes and numbers. Here we report a case of ICCS in a 50-year-old man with a brief review of the literature and a discussion on pathogenesis.

\section{Case presentation}

A healthy looking, 50-year-old Nepali man came to our clinic with a complaint of multiple growths on his scrotum for 15 years. The growths started as a single lesion on the right side of his scrotum, with the gradual appearance of similar lesions on other parts. Several of these lesions coalesced at various places to form large-sized nodules. The condition was mostly asymptomatic with an occasional complaint of itching. There was no

(c) The Author(s). 2018 Open Access This article is distributed under the terms of the Creative Commons Attribution 4.0 International License (http://creativecommons.org/licenses/by/4.0/), which permits unrestricted use, distribution, and 


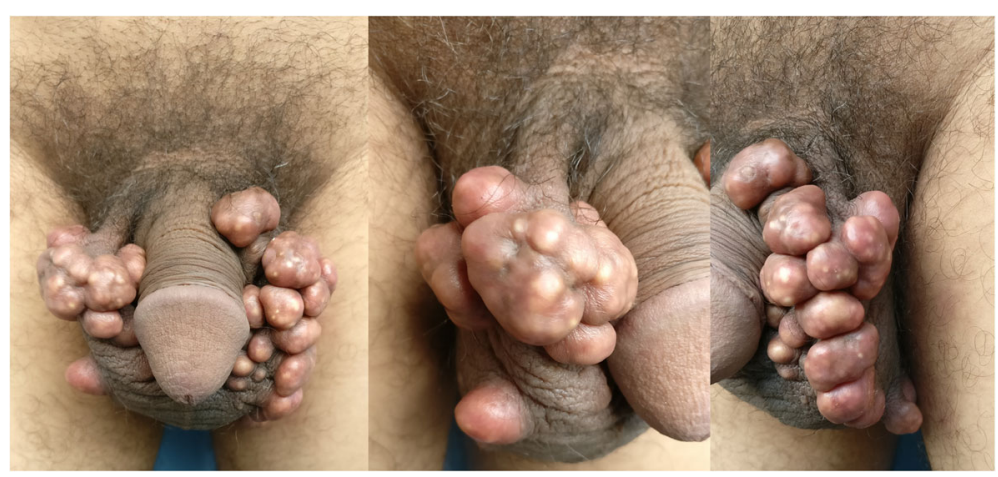

Fig. 1 Multiple pink to brown nodules, variable in size involving a large part of the scrotum

history of pain, burning sensation, trauma, ulceration, or discharge. The lesions did not interfere with urination or sexual activities. He was worried because of the increasing size of the growth and hence came to us for advice. He did not give a history of any systemic illness including metabolic, autoimmune, or malignant disorders. There was also no history of a similar complaint in his family.

On physical examination, multiple pink to brown nodules ranging in size from $0.5 \times 0.5 \times 0.5 \mathrm{~cm}$ to $3 \times 3 \times 1$ $\mathrm{cm}$ involving almost half of his scrotum were noticed (Fig. 1). The skin over the nodules was shiny with several yellowish points indicative of underlying calcium deposition. The skin surrounding the nodules, testis, and penis was normal on palpation. The nodules were painless and firm in consistency. On laboratory examinations the following were found to be within normal limits: serum calcium, phosphorus, parathyroid hormone, and vitamin D hormone levels; uric acid; alkaline phosphatase; and lipid profile. Based on clinical features and laboratory reports, a diagnosis of ICCS was made.
He was advised a scrotectomy under spinal anesthesia, which he refused. The nodules were excised under local anesthesia in several sittings. The skin was sutured using chromic catgut (4-0). His postoperative period was unremarkable with good cosmetic result and no evidence of recurrence in a 1-year follow-up period. The cut section of nodules showed solid white to yellow homogenous areas. Histopathological examination revealed skin tissue lined by keratinized stratified squamous epithelium. The underlying dermis had areas of fibrosis and calcification (Fig. 2). Numerous multinucleated giant cells were also seen (Fig. 3a and b). An obvious cystic structure was absent.

\section{Discussion}

ICCS is a benign, mostly asymptomatic, condition; although it appears early, patients generally present during the third to fourth decade of life. The symptom-free nature of the disease may be the reason for delayed presentation. The disease presents as slow-growing yellowish nodules in the scrotum, single to multiple in numbers,

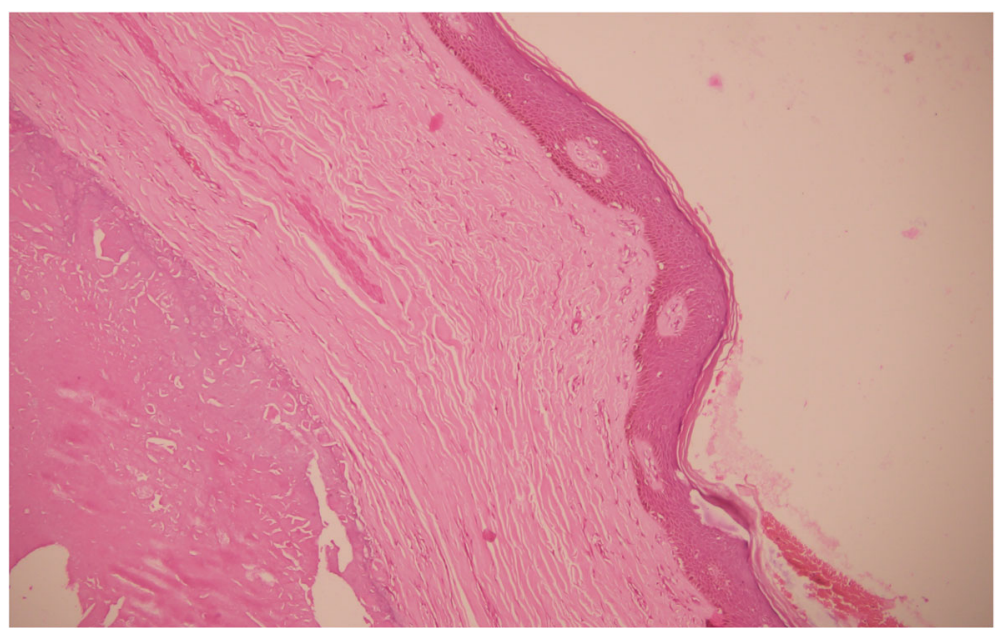

Fig. 2 Hematoxylin and eosin stain $(100 x)$ : keratinized stratified squamous epithelium lining the skin, with underlying dermis showing areas of fibrosis and calcification 


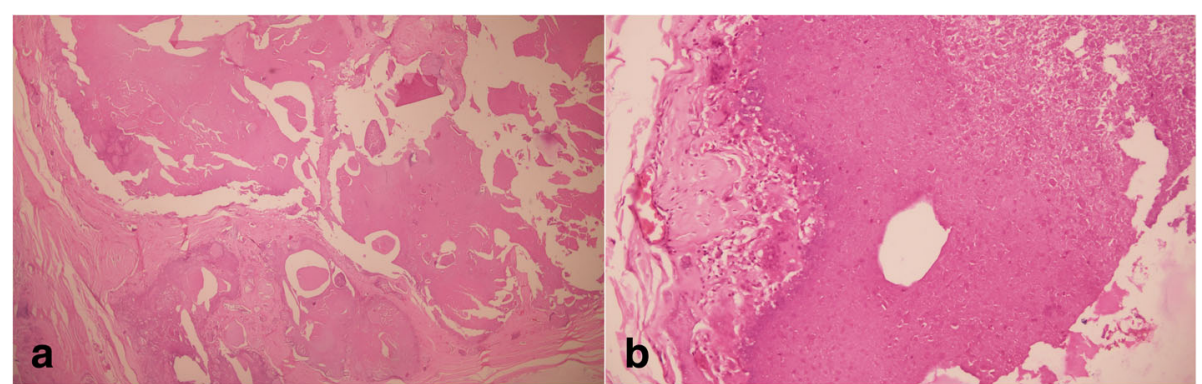

Fig. 3 a and $\mathbf{b}$ Hematoxylin and eosin stain (3a is 100x while 3b is 200x): underlying dermis showing areas of fibrosis, calcification, and multinucleated giant cells

with varying sizes. It may sometimes be associated with itching or the nodule may break down to discharge chalky material. Infection of the nodules is uncommon. Although the first case was described by Lewinski in 1883 [2], the first review was provided by Shapiro et al. in 1970 [5]. Lewinski is also credited with the introduction of the term idiopathic calcinosis of scrotum. The clinical features of a few case series with five or more cases reported until now are compared in Table 1. We excluded a case series that had cases of dystrophic calcinosis.

ICCS is a clinical and histological diagnosis. The size, number, skin surface, and age of onset hint toward ICCS, while confirmation is always done on histopathology. A nodular lesion in the scrotum has several differential diagnoses which include steatocystoma multiforme, angiokeratoma, lipomata, fibromata, and lymphangioma circumscriptum [6]. However, only calcified sebaceous cyst would make a difficult differential clinically. Others can be easily ruled out.

As the condition is idiopathic, the exact etiology is not known. However, there is an intense debate going on to challenge the idiopathic nature of the disease. Several authors feel that ICCS is actually a misnomer and the underlying cause is the calcification of the epidermoid or epidermal cysts of the scrotum [7-9]. In a case series of five patients with multiple calcified nodules of the scrotum, Noel et al. examined 15 nodules from each patient and concluded that these nodules were calcified epidermoid cysts [7]. In another study of 20 patients with

Table 1 Clinical features of idiopathic calcinosis cutis of the scrotum from various case reports

\begin{tabular}{|c|c|c|c|c|c|c|}
\hline Authors & Shapiro et al. [5] & Akosa et al. [19] & Wright et al. [10] & Gormally et al. [6] & Baruchin et al. [20] & Andola et al. [14] \\
\hline Number of cases & $13^{*}$ & 5 & 9 & 11 & 5 & 20 \\
\hline Year & 1970 & 1989 & 1991 & 1992 & 1998 & 2017 \\
\hline $\begin{array}{l}\text { Mean age of } \\
\text { presentation }\end{array}$ & 47.3 years & 39.6 years & 38.66 years & $\begin{array}{l}{ }^{* *} \text { Mean age of } \\
\text { onset: } 27.4 \text { years }\end{array}$ & 36.8 years & 37.2 years \\
\hline Number of nodules & One to $>100$ & One to 36 & Several & $\begin{array}{l}4-10 \\
(2 \text { cases })\end{array}$ & One to multiple & One to multiple \\
\hline Size range of nodules & $1 \mathrm{~mm}$ to $3 \mathrm{~cm}$ & Not stated & A few $\mathrm{mm}$ to $2 \mathrm{~cm}$ & $\begin{array}{l}\text { Up to } 2 \mathrm{~cm} \\
\text { ( } 2 \text { cases) }\end{array}$ & $2 \mathrm{~mm}$ to $1.5 \mathrm{~cm}$ & 0.5 to $3.5 \mathrm{~cm}$ \\
\hline $\begin{array}{l}\text { Most common } \\
\text { symptoms }\end{array}$ & $\begin{array}{l}\text { Itching (5/13) } \\
\text { Asymptomatic (2/13) } \\
\text { Breakdown and } \\
\text { discharge }(4 / 13) \\
\text { Recurrent }(1 / 13)\end{array}$ & $\begin{array}{l}\text { Asymptomatic } \\
(4 / 5) \\
\text { Discharge }(1 / 5)\end{array}$ & $\begin{array}{l}\text { Asymptomatic } \\
\text { (mostly) } \\
\text { Itching (several) } \\
\text { Discharge (in some) }\end{array}$ & $\begin{array}{l}\text { Itching, breakdown } \\
\text { and discharge }(1 / 2) \\
\text { Asymptomatic (1/2) }\end{array}$ & $\begin{array}{l}\text { Asymptomatic } \\
(4 / 5) \\
\text { Breakdown and } \\
\text { discharge }(1 / 5)\end{array}$ & $\begin{array}{l}\text { Asymptomatic } \\
(16 / 20) \\
\text { Breakdown and } \\
\text { discharge }(4 / 20)\end{array}$ \\
\hline Clinical diagnosis & $\begin{array}{l}\text { Sebaceous cyst } \\
(8 / 13) \\
\text { Cyst }(1 / 13) \\
\text { Not stated (3/13) } \\
\text { Calcified fibroma } \\
(1 / 13)\end{array}$ & $\begin{array}{l}\text { Sebaceous } \\
\text { cyst }(5 / 5)\end{array}$ & Not stated & Not stated & Not stated & $\begin{array}{l}\text { Sebaceous cyst } \\
(11 / 20) \\
\text { Epidermal inclusion } \\
\text { cyst }(6 / 20)\end{array}$ \\
\hline $\begin{array}{l}\text { Evidence of epithelial } \\
\text { lining in histopathology }\end{array}$ & No & Yes $(1 / 5)$ & No & Yes $(1 / 11)$ & No & No \\
\hline $\begin{array}{l}\text { Evidence of calcification } \\
\text { elsewhere in body }\end{array}$ & No & No & No & No & No & No \\
\hline
\end{tabular}

Veress et al. reported a case series with six cases from Sudan [21]. However, we could not retrieve the full paper, and hence we did not include it in our list *Although Shapiro et al. mention 35 cases in their review, we have included only 13 of their own patients for analysis in the table

**Age of presentation cannot be determined 
scrotal calcinosis, calcification of hair follicular or epidermal cysts were the reason for calcified nodules [8]. The follicular cyst dilates, followed by calcification around and within the cyst, with eventual disappearance of epithelial lining. However, what leads to this calcification is not known. Trauma may be a triggering factor in some cases [6]. Wright et al. had earlier challenged this theory by using antikeratin monoclonal antibodies to find deposits of keratin in or around the calcium aggregates [10]. They failed to identify any keratin deposits, which lends support to the idiopathic nature of the disease. In recent years, Yuyucu Karabulut et al. further reiterated the dystrophic theory by demonstrating the presence of keratin fibers and calcium granules in the surrounding dermis [11]. It is not only the epidermoid cyst, but dystrophic calcification of eccrine glands [12] and dartos muscle [13] are also offered as alternative theories. The histopathological finding of our case did not have any evidence of epithelial lining. There were calcifications with the presence of multinucleated giant cells.

To label the condition as idiopathic, the presence of calcification elsewhere must be ruled out. A thorough biochemical and hormonal profile would help delineate the cause. If the condition is truly idiopathic, the laboratory investigations unequivocally fall within normal limits. Not one particular diagnostic modality is helpful. Fine-needle aspiration cytology, ultrasonography, and $\mathrm{X}$-ray have been ordered with limited usefulness [14]. As the condition is benign and mostly asymptomatic, the treatment is for aesthetic purpose, unless the nodules start discharging or become itchy. Excision followed by scrotal reconstruction is the treatment of choice. It leaves a good cosmetic result with low chances of recurrence. Even the smallest nodule must be removed to prevent recurrence. In the genitalia, the scrotum is not the only site of idiopathic calcification. Cases of vulval $[15,16]$ and penile $[17,18]$ calcinosis have been documented.

\section{Conclusions}

ICCS is a benign condition, which remains mostly asymptomatic. It presents as progressive multiple nodules of varying numbers and sizes. A histopathological evaluation reveals areas of calcification. The cause is either dystrophic calcification of cysts or idiopathic. Excision is the treatment of choice.

\section{Abbreviation}

ICCS: Idiopathic calcinosis cutis of the scrotum

\section{Acknowledgements}

None to declare.

\section{Funding}

The authors declare that there was no source of funding.
Availability of data and materials

Data sharing is not applicable to this article, because no data were generated or analyzed during the study. All data (clinical and histopathological) gathered for this study are included in this published article.

\section{Authors' contributions}

MMAS designed the manuscript. MMAS and UP were involved in clinical diagnosis and treatment. AR took part in histopathological examination and literature search. MMAS, AR, and UP collected and assembled the data. MMAS critically reviewed the manuscript. All of the authors read and approved the final version of the manuscript.

\section{Ethics approval and consent to participate}

Case reports do not require ethical approval; however, the general informed consent process includes obtaining patient approval for anonymous use of relevant clinical and surgical information and photographs.

\section{Consent for publication}

Written informed consent was obtained from the patient for publication of this case report and any accompanying images. A copy of the written consent is available for review by the Editor-in-Chief of this journal.

\section{Competing interests}

The authors declare that they have no competing interests.

\section{Publisher's Note}

Springer Nature remains neutral with regard to jurisdictional claims in published maps and institutional affiliations.

\section{Author details}

'Department of Dermatology and Venereology, Institute of Medicine, Tribhuvan University, Maharajgunj, Kathmandu, Nepal. ${ }^{2}$ Department of Pathology, Institute of Medicine, Tribhuvan University, Maharajgunj, Kathmandu, Nepal.

Received: 8 October 2018 Accepted: 11 November 2018

Published online: 12 December 2018

\section{References}

1. Valenzuela A, Chung L. Calcinosis: pathophysiology and management. Curr Opin Rheumatol. 2015;27(6):542-8.

2. Lewinski HM. Lymphangiome der Haut mit Verkalklem Inhalt. Arch Pathol Anat. 1883;91:371-4.

3. Saad AG, Zaatari GS. Scrotal calcinosis: is it idiopathic? Urology. 2001;57(2): 365.

4. Dini $M$, Colafranceschi $M$. Should scrotal calcinosis still be termed idiopathic? Am J Dermatopathol. 1998;20(4):399-402.

5. Shapiro L, Platt N, Torres-Rodriguez VM. Idiopathic calcinosis of the scrotum. Arch Dermatol. 1970;102(2):199-204.

6. Gormally S, Dorman T, Powell FC. Calcinosis of the scrotum. Int J Dermatol. 1992;31(2):75-9.

7. Noel B, Bron C, Kunzle N, De Heller M, Panizzon RG. Multiple nodules of the scrotum: histopathological findings and surgical procedure. A study of five cases. J Eur Acad Dermatol Venereol. 2006;20(6):707-10.

8. Shah V, Shet T. Scrotal calcinosis results from calcification of cysts derived from hair follicles: a series of 20 cases evaluating the spectrum of changes resulting in scrotal calcinosis. Am J Dermatopathol. 2007;29(2):172-5.

9. Song $\mathrm{DH}$, Lee $\mathrm{KH}$, Kang $\mathrm{WH}$. Idiopathic calcinosis of the scrotum: histopathologic observations of fifty-one nodules. J Am Acad Dermatol. 1988;19(6):1095-101.

10. Wright S, Navsaria H, Leigh IM. Idiopathic scrotal calcinosis is idiopathic. J Am Acad Dermatol. 1991:24(5):727-30.

11. Yuyucu Karabulut Y, Kankaya D, Senel E, Dolek Y, Uslu A, Sertcelik A. Idiopathic scrotal calcinosis: the incorrect terminology of scrotal calcinosis. $G$ Ital Dermatol Venereol. 2015;150(5):495-9.

12. Dare AJ, Axelsen RA. Scrotal calcinosis: origin from dystrophic calcification of eccrine duct milia. J Cutan Pathol. 1988;15(3):142-9.

13. King DT, Brosman S, Hirose FM, Gillespie LM. Idiopathic calcinosis of scrotum. Urology. 1979;14(1):92-4. 
14. Andola S, Tandon T, Patil A. Clinical-epidemiological, cytological and histopathological study of idiopathic calcinosis cutis of the scrotum. J Clin Diagn Res. 2017;11(11):EC01-EC4.

15. Jamaleddine FN, Salman SM, Shbaklo Z, Kibbi AG, Zaynoun S. Idiopathic vulvar calcinosis: the counterpart of idiopathic scrotal calcinosis. Cutis. 1988; 41(4):273-5.

16. Coban YK, Aytekin AH, Aydin EN. Idiopathic Calcinosis Cutis of the Vulva. Indian J Dermatol. 2013;58(6):464-6.

17. Cohen PR, Tschen JA. Idiopathic calcinosis cutis of the penis. J Clin Aesthet Dermatol. 2012;5(12):23-30.

18. Katoh N, Okabayashi K, Wakabayashi S, Kishimoto S, Yasuno H. Dystrophic calcinosis of the penis. J Dermatol. 1993;20(2):114-7.

19. Akosa AB, Gilliland EA, Ali MH, Khoo CT. Idiopathic scrotal calcinosis: a possible aetiology reaffirmed. Br J Plast Surg. 1989;42(3):324-7.

20. Baruchin AM, Baruffaldi Preis FW, Cavallini M, Ben-Dor D. Idiopathic calcinosis of the scrotum: report of five cases and review of the literature. Eur J Plast Surg. 1998;21(6):282-5.

21. Veress B, Malik M. Idiopathic scrotal calcinosis. A report of six cases from the Sudan. East Afr Med J. 1975;52:705-10

Ready to submit your research? Choose BMC and benefit from:

- fast, convenient online submission

- thorough peer review by experienced researchers in your field

- rapid publication on acceptance

- support for research data, including large and complex data types

- gold Open Access which fosters wider collaboration and increased citations

- maximum visibility for your research: over $100 \mathrm{M}$ website views per year

At BMC, research is always in progress.

Learn more biomedcentral.com/submissions 